\section{Mode of Action of Isonicotinic Hydrazide}

IN our earlier report we directed attention to the importance of chelation as an essential step in the anti-tuberculous activity of isonicotinic hydrazide (isoniazid) ${ }^{1}$. It was impossible to decide whether the chelating action with a metal or metals took place before (in the medium) or after adsorption on the bacterial cell.

Since then we have had the opportunity of examining the activity in vitro and in vivo of the relatively insoluble cupric complex of isoniazid :

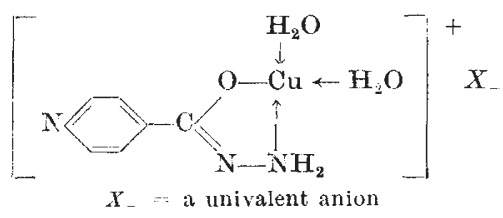

The results now reported (see Table 1) indicate that this complex is highly active. Thus, it might now be postulated that isoniazid is probably inactive in the absence of a chelating metal, and that its antituberculous activity is, in fact, due to its metal complex, in this instance the cupric derivative. These findings are strongly reminiscent of those obtained in earlier studies of the mode of action of 8-hydroxyquinoline (oxine) $)^{2}$.

Table 1. Activity of isoNicotinic HydRazide and its Cuprio Chelate Complex

\begin{tabular}{|c|c|c|}
\hline \multirow[b]{2}{*}{ Compound } & \multicolumn{2}{|c|}{ Anti-tuberculous activity } \\
\hline & $\begin{array}{c}\text { In vitro (ref. 5) } \\
\text { Tuberculostatic end- } \\
\text { point. Medium : syn- } \\
\text { thetic serum-synthetic }\end{array}$ & $\begin{array}{l}\text { In vivo (ref. 3) } \\
\text { Healing ulcer } \\
\text { response }\end{array}$ \\
\hline $\begin{array}{l}\text { Isonicotinic hydra- } \\
\text { zide (isoniazid) }\end{array}$ & \begin{tabular}{cc|}
$2,048,000$ & $2,048,000$ \\
$(0.07$ & $(0.07$ \\
$\mu \mathrm{gm} . / \mathrm{ml})$. & $\mu \mathrm{gm} . / \mathrm{ml})$.
\end{tabular} & $\begin{array}{l}20 \mathrm{mgm} \text {. } / \mathrm{kgm} \text {. weekly } \\
\text { I.M. } \\
H R 100 \text { in } 28 \text { days. }\end{array}$ \\
\hline $\begin{array}{l}\text { Cupric complex of } \\
\text { isoniazid }\end{array}$ & \begin{tabular}{cc|}
$4,096,000$ & 512,000 \\
$(0 \cdot 08$ & $(0 \cdot 6$ \\
$\mu \mathrm{gm} . / \mathrm{ml})$. & $\mu \mathrm{gm} . / \mathrm{ml})$.
\end{tabular} & $\begin{array}{l}20 \text { mgm. } / \mathrm{kgm} \text {. weekly } \\
\text { I.M. } \\
H R 99 \text { in } 28 \text { days. }\end{array}$ \\
\hline
\end{tabular}

It will be noted that the activity in vivo, examined by the healing-ulcer technique previously reported ${ }^{3}$, is extremely high, two injections effecting 85 per cent cure ( $H R$ value 85 ) in three weeks and 99 per cent cure in 28 days after three injections.

This copper derivative appears to be as active as isoniazid, verazide ${ }^{4}$ or any drug we have tested so far. However, it exhibits a profound local and general toxicity in mice and guinea pigs. During treatment of guinea pigs by intramuscular injection, a severe gangrenous necrosis and ulceration developed at the site of injection, and in mice the acute toxicity $(L D 50)$ was as low as $36 \mathrm{mgm}$. $/ \mathrm{kgm}$. body-weight compared with $200 \mathrm{mgm}$. $/ \mathrm{kgm}$. for isoniazid itself.

The interest in these findings centres on the demonstration that the copper-isoniazid chelate complex is active in vitro and in vivo under conditions in which it is unlikely to break down to isoniazid. This observation, taken in conjunction with our earlier findings ${ }^{1}$, has led us to conclude that the antituberculous activity of isoniazid is expressed after it has formed a chelate metal complex in the medium or the animal body in which it is acting. The identity of the complexing metal in vitro or in vivo is still unknown, and the activity of other metal complexes is being investigated,
We thank the National Health and Medical Research Council of Australia and the Rockefeller Foundation for partial financial support.

$$
\begin{aligned}
& \text { S. D. Rubbo } \\
& \text { JANICE EDGAR }
\end{aligned}
$$

School of Bacteriology, University of Melbourne.

\section{Nov. 4.}

J. CYMERMAN-CRAIG

G. N. Vaughan

D. WiLlis

Department of

University of Sydney.
Organic Chemistry,

I Cymerman-Craig, Rubbo, Willis and Edgar, Nature, 176, 34 (1955). 2 Rubbo, Albert and Gibson, Brit. J. Exp. Path., 31, 425 (1950).

3 Rubbo and Pierson, Amer. Rev. Tuberc., 68, 48 (1953).

4 Rubbo and Cymerman-Craig, Nature, 176, 887 (1955).

${ }^{5}$ Cymerman-Craig, Rubbo and Pierson, Brit. J. Exp. Path., 35, 478 (1954).

\section{Reduction to Normal Levels of the High Erythrocyte Sedimentation-Rates in Apparently Healthy South African Bantu Men}

In the tropics and semitropics, unusually high values for erythrocyte sedimentation-rates are common among apparently healthy individuals. Thus, among seventy-five medically fit young Indian medical students, the mean rate (Wintrobe's method) ${ }^{1}$ was $11 \cdot 2 \pm 9 \cdot 4$, range $0.5-30 \mathrm{~mm}$.; high values are assumed to be pathological, although the cause was unknown ${ }^{2}$

Neither malnutrition nor under-nutrition (unless very severe) is believed directly to influence erythrocyte sedimentation-rate ${ }^{3}$. Nevertheless, we find that although very high rates are common among different regional groups of apparently healthy Bantu mine-workers, the mean high values become reduced to within normal limits after subjects, without any medical treatment, have consumed for four-fifteen months the excellent diet provided in the mine compounds.

The Bantu mine-workers were eighteen to forty years old, in good physical condition, not anæmic, and free from radiological tuberculosis. No significant enlargement of liver, spleen or lymph nodes was apparent. Subjects were variously parasitized, particularly the tropical group. The KolmerWassermann test for syphilis was positive in 4 per cent of cases. The majority showed liver dysfunction as revealed by the common biochemical tests on serum.

Workers came from areas where the diet is usually adequate in calories and gross protein, but is low. in animal protein, fat and certain mineral salts and vitamins. The mine compound diet, which may be eaten to satiety, is nutritionally adequate.

'The erythrocyte sedimentation-rate was determined on oxalated blood using Wintrobe's method', two technicians working in parallel, and determinations being completed within $3 \mathrm{hr}$.

In Table 1, only in the mixed group do data refer to the same individuals examined at the beginning and end of periods of service.

Our results revealed an equal degree of abnormality of erythrocyte sedimentation-rate among recruits with and without previous periods of service in the mines : this finding suggests that the normal values found on leaving the mines rise again on returning for some months to conditions of tribal life.

The dramatic and unexpected changes in erythrocyte sedimentation-rate found in these outwardly healthy subjects are not due to any medical treat- 